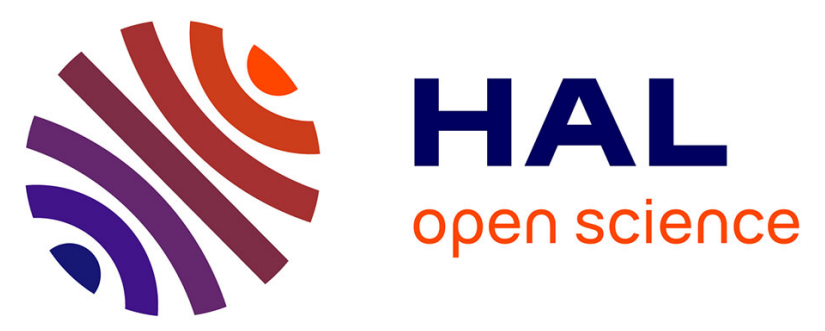

\title{
Efficient Conjugation of Oligosaccharides to Polymer Particles through Furan/Maleimide Diels-Alder Reaction: Application to the Capture of Carbohydrate-Binding Proteins
}

Antoine Petrelli, Eric Samain, Stéphanie Pradeau, Sami Halila, Sébastien Fort

\section{To cite this version:}

Antoine Petrelli, Eric Samain, Stéphanie Pradeau, Sami Halila, Sébastien Fort. Efficient Conjugation of Oligosaccharides to Polymer Particles through Furan/Maleimide Diels-Alder Reaction: Application to the Capture of Carbohydrate-Binding Proteins. ChemBioChem, 2017, 18 (2), pp.206-212. 10.1002/cbic.201600509 . hal-02115628

\section{HAL Id: hal-02115628 \\ https://hal.science/hal-02115628}

Submitted on 30 Apr 2019

HAL is a multi-disciplinary open access archive for the deposit and dissemination of scientific research documents, whether they are published or not. The documents may come from teaching and research institutions in France or abroad, or from public or private research centers.
L'archive ouverte pluridisciplinaire HAL, est destinée au dépôt et à la diffusion de documents scientifiques de niveau recherche, publiés ou non, émanant des établissements d'enseignement et de recherche français ou étrangers, des laboratoires publics ou privés. 


\title{
Efficient Conjugation of Oligosaccharides to Polymer Particles by Furan/Maleimide Diels-Alder Reaction: Application to the Capture of Carbohydrate-Binding Proteins
}

\author{
Antoine Petrelli, ${ }^{a b}$ Eric Samain, ${ }^{a b}$ Stéphanie Pradeau, ${ }^{a b}$ Sami Halila, ${ }^{a b}$ Sébastien Fort ${ }^{a b *}$
}

\begin{abstract}
Glycan-protein interactions play a crucial role in physiological and pathological events. Hence, improving the isolation of carbohydrate-binding proteins (i.e. lectins and anti-glycan antibodies) from complex media can not only lead to a better understanding of their function, but also provides solutions for public health issues, such as water contamination or the need for universal blood plasma. Herein, we report a rapid and efficient method to produce carbohydrate-based affinity adsorbents combining enzymatic synthesis and metal-free click chemistry. Simple as well as complex glycans (maltose, blood group antigens A, B and $\mathrm{H}$ ) were readily modified by the addition of a furyl group at their reducing end without the need for protecting groups and then efficiently conjugated to maleimide-activated Sepharose particles via a Diels-Alder reaction. These neoglycoconjugates showed high efficiency for the purification of lectins (Concanavalin A and Ulex europaeus agglutinin) as well as for the capture of anti-A and anti-B blood group antibodies, opening new prospects for glycoproteomics and for the development of universal blood plasma.
\end{abstract}

\section{Introduction}

All cells and eukaryotic cells in particular, are coated by a glycocalyx constituted of glycoconjugates, i.e. glycolipids and glycoproteins, of extraordinary diversity. The glycan moieties are located on the external face of the cell membrane, and act as a recognition signal, thereby fulfilling unique biological functions. Specific interactions between these carbohydrates and lectins or anti-glycan antibodies are involved in many biological events in healthy and in diseased states of living organisms. In particular, carbohydrate-directed cell adhesion appears to be important in cellular communication, in the immune response and in infection by bacteria and viruses. ${ }^{[1]}$

Synthetic neoglycoconjugates in which a glycan is covalently linked to a protein, a lipid or a solid matrix have proven to be efficient tools to study structure-function relationships of complex carbohydrates. They also have many practical applications for the diagnosis and treatment of various diseases. For example, immobilized carbohydrates constitute versatile affinity adsorbents for the purification of enzymes, ${ }^{[2]}$ lectins ${ }^{[3]}$ and antibodies. ${ }^{[4]}$ The

[a] Dr A. Petrelli, Dr E. Samain, S. Pradeau, Dr S. Halila, Dr S.Fort* Univ. Grenoble Alpes, CERMAV, F-38000 Grenoble, France E-mail: Sebastien.Fort@cermav.cnrs.fr

[b] Dr A. Petrelli, Dr E. Samain, S. Pradeau, Dr S. Halila, Dr S.Fort CNRS, CERMAV, F-38000 Grenoble, France

Supporting information for this article is given via a link at the end of the document. depletion of anti-glycan antibodies in sera is beneficial for therapeutic developments and analytical studies of autoimmune diseases, such as the Guillain-Barré syndrome and Crohn's disease..$^{[5]}$ Carbohydrate-based immunoadsorbents have been shown to be efficient and safe in organ transplantation across the ABO blood group barrier. ${ }^{[6]}$ They also hold promise to improve universal blood plasma supply. ${ }^{[7]}$ Indeed, plasma which contains clotting factors, immunoglobulins and albumin is used in every day medicine, emergencies and surgical medicine to treat clotting disorders, burn, and shock victims. However, universal $A B$ plasma, which does not contain any antibodies against either $A$ or $B$ antigens, is usually in short supply because of the scarcity of this blood group.

The production of neoglycoconjugates for the above-mentioned applications is hindered by the lack of an efficient method to synthesize complex oligosaccharides and to conjugate them without extensive protecting-group manipulation. Enzymatic syntheses, and particularly those employing microbial cell factories, have considerably improved access to complex oligosaccharides. High density culture of metabolically engineered $E$. coli cells can produce a wide range of mammalian molecules on a multigram scale, including gangliosides, ${ }^{[8]}$ globosides ${ }^{[9]}$ and Lewis antigens. ${ }^{[10]}$ Current procedures used to immobilize native oligosaccharides on solid matrices can for their part be classified into two categories. The first involves the nucleophilic attack of any hydroxyl group present on the carbohydrate onto an electrophile, typically an epoxide, ${ }^{[11]}$ a cyanate $^{[12]}$ or a vinyl sulfone ${ }^{[13]}$ ester. The lack of regioselectivity of these reactions does not allow a controlled orientation of the ligand, thus restricting their use to commonly available and cheap mono- and disaccharides. The second strategy consists of the specific modification of the reducing end of the glycan by reductive amination ${ }^{[14]}$ or by the formation of hydrazone ${ }^{[15]}$ or oxime $^{[16]}$ linkages. Although these procedures are efficient on an analytical scale, large-scale applications have the major drawback of requiring the use of harmful chemicals. Furthermore, they also often lead to the loss of the cyclic structure of the modified sugar unit, which may result in a lower affinity for the target protein. ${ }^{[17]}$

The advent of click chemistry in 2001 sparked a renewed interest in the development of effective methods for the mild and sitespecific conjugation of biomolecules including carbohydrates. The copper(I)-catalyzed azide-alkyne cycloaddition (CuAAC), the most prominent example of click-reactions, has found myriad applications in chemical biology. ${ }^{[18]}$ 

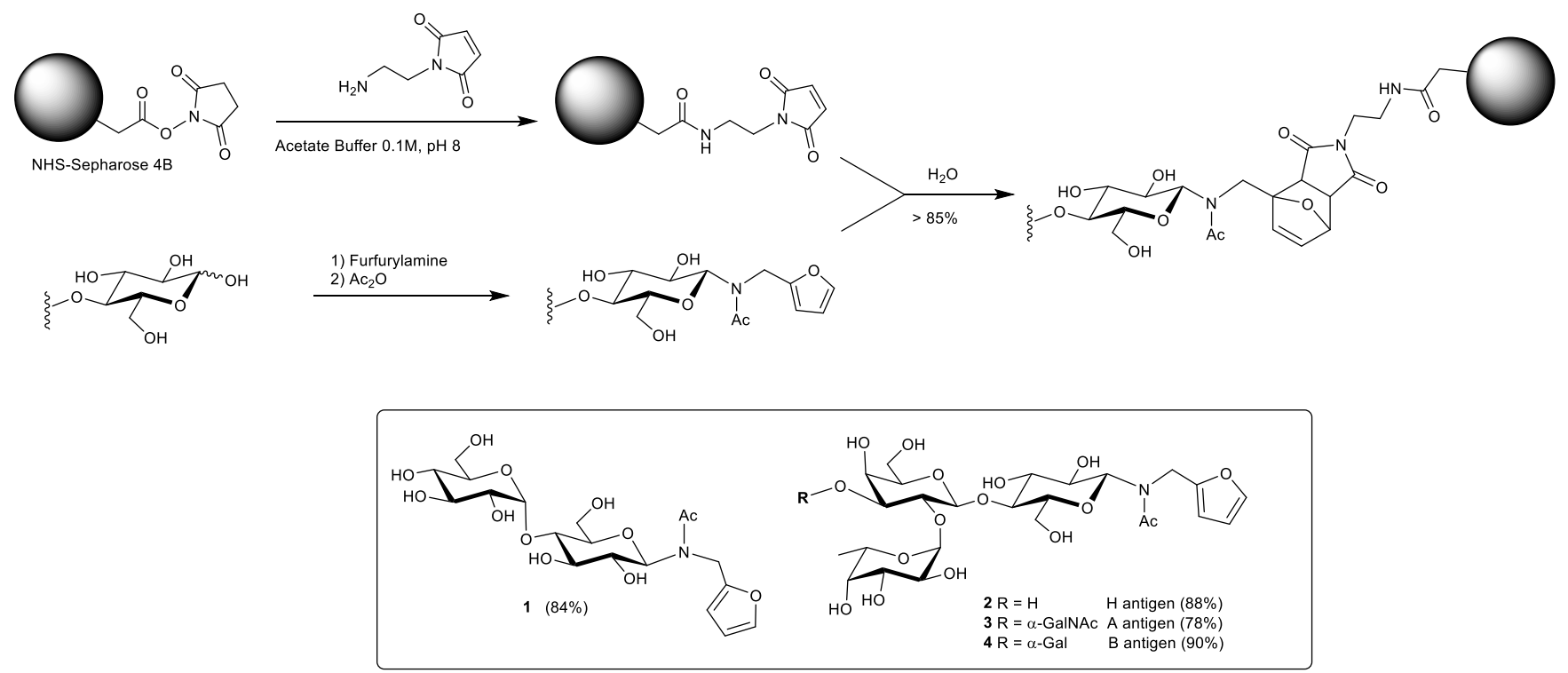

Scheme 1. General synthesis route for the preparation of carbohydrate-modified Sepharose particles and chemical structures of furyl-modified maltose (1) and furyl-modified blood group antigens $\mathrm{H}(2), \mathrm{A}(\mathbf{3})$ and $\mathrm{B}(\mathbf{4})$

The Diels-Alder cycloaddition, is also an attractive reaction for the conjugation of biomolecules, since besides being a chemoselective, reversible and catalyst-free reaction, it is fast and efficient in aqueous media. ${ }^{[19]}$ Diels-Alder reactions have been successfully applied to the preparation of oligosaccharide-based antibacterial vaccines ${ }^{[20]}$ and biosensors. ${ }^{[21]}$ Usual dienes employed for these syntheses are cyclopentadiene, heptadienoic acid or tetrazine derivatives. Curiously, the furan group has been scarcely used for the conjugation of biomolecules except for a few examples such as for the synthesis of peptide-oligonucleotide conjugates $^{[22]}$ or DNA-porphyrin conjugates. ${ }^{[23]}$ However, the furan-maleimide cycloaddition currently meets a great success in material science as an effective crosslinking method especially for the preparation of hydrogels. ${ }^{[24]}$

Herein, we describe an efficient protocol for the preparation of new carbohydrate-based affinity adsorbents using furanmaleimide cycloaddition. Blood group antigens $H,{ }^{[25]} A$ and $B^{[26]}$ were produced in $E$. coli and readily turned into $\mathrm{N}$-furfurylglycosylamides before being conjugated to maleimide-activated Sepharose particles via a Diels-Alder reaction. The resulting neoglycoconjugates were then assessed as affinity adsorbents for the purification of lectins and for the capture of antibodies. The synthesis route for these new carbohydrate-based affinity adsorbents is depicted in Scheme 1.

\section{Results and Discussion}

Sepharose 4B, which is a well-proven agarose gel filtration base matrix for affinity chromatography, was selected as the solid support. The commercially available succinimidyl ester-activated form was reacted with $\mathrm{N}$-(2-aminoethyl)maleimide ${ }^{[27]}$ to introduce a dienophile group which is amenable to a Diels-Alder reaction.
The unreacted activated esters were then hydrolyzed in mild basic conditions to avoid the degradation of the maleimide moiety. The conversion yield was at least $85 \%$, as determined by the conductimetric titration of unreacted and total theoretical reactive sites. Infrared (IR) spectroscopy analysis further confirmed the introduction of the maleimide groups by the absence of the characteristic succinimidyl ester peaks at 1738 and $1782 \mathrm{~cm}^{-1}$ and the presence of the maleimide carbonyl peak at $1710 \mathrm{~cm}^{-1}$ (Figure $1)$.

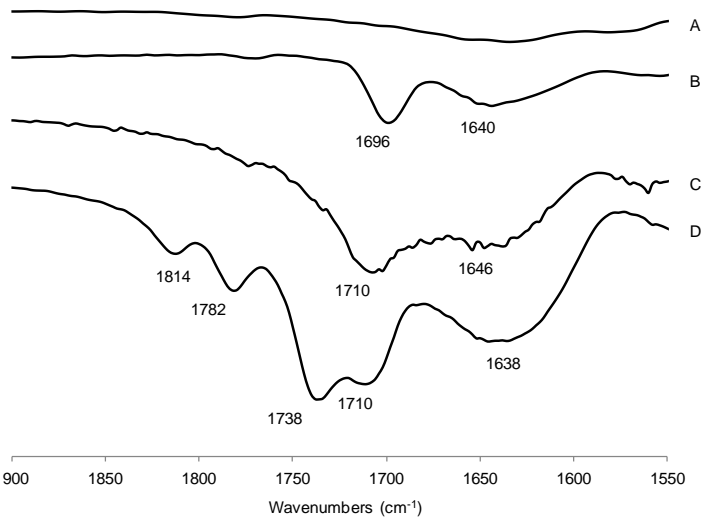

Figure 1. IR spectrum of modified Sepharose in the carbonyl region: A) Sepharose, B) Maltose-modified Sepharose, C) Maleimide-activated Sepharose, D) NHS-activated Sepharose. 
The modification and conjugation of carbohydrates were then investigated on maltose as a model before moving to more complex oligosaccharides. Furyl-maltose conjugate $\mathbf{1}$ was prepared in $84 \%$ yield by reacting unprotected maltose in neat furylamine to afford a transient glycosylamine that was made nonhydrolyzable by selective $\mathrm{N}$-acylation in methanol. This carbohydrate-modification method which was originally developed by Lokhoff et al. ${ }^{[28]}$ with aliphatic amines and disaccharides for the synthesis of glycolipid analogues then showed a great versatility when applied to various amines and sugars. Among the different examples reported in the literature about the use of this reaction, one could notice the direct immobilization of reductive oligosaccharides onto polymer beads for the preparation of chromatography adsorbents ${ }^{[29]}$ and the synthesis of glycosylated carriers for gene transfection. ${ }^{[30]}$ Glycosylamides derived from unsaturated amines such as allylamine or propargylamine also have been shown to be interesting intermediates in the synthesis of glycoconjugates by thiol-ene and CuAAC reactions. ${ }^{[31]}$ Our group has efficiently used this approach for the preparation of drug nanocarriers ${ }^{[32]}$ and nanoorganized thin films ${ }^{[3]}$ by self-assembly of oligosaccharidebased block copolymers.

The furyl-maleimide Diels-Alder reaction was carried out in water under gentle stirring of the Sepharose particles with a fivefold excess of 1 . The time-course of the reaction was monitored by IR spectroscopy (Figure 1). During the conjugation, the alkene moiety of the maleimide was consumed in the cycloaddition, thus shifting the maleimide carbonyl signal from $1710 \mathrm{~cm}^{-1}$ to $1696 \mathrm{~cm}$ ${ }^{1}$. Although an excess of furyl-maltose 1 was required to drive the reaction to completion, it was recovered unaltered after rinsing the particles. IR analysis suggested that all maleimide groups underwent complete reaction.

For confirmation, we determined the maltose content on the solid matrix by enzymatic digestion. To do so, the particles were incubated with an excess of recombinant amyloglucosidase $\mathrm{G2}^{[34]}$ and the amount of glucose released in the supernatant was assessed using the BCA reducing sugar assay. We thus confirmed that the Diels-Alder ligation in water proceeded with an extremely satisfactory yield of at least $85 \%$. Moreover, the efficiency of enzymatic hydrolysis with amyloglucosidase also confirmed the availability of the immobilized carbohydrate moiety for protein binding.

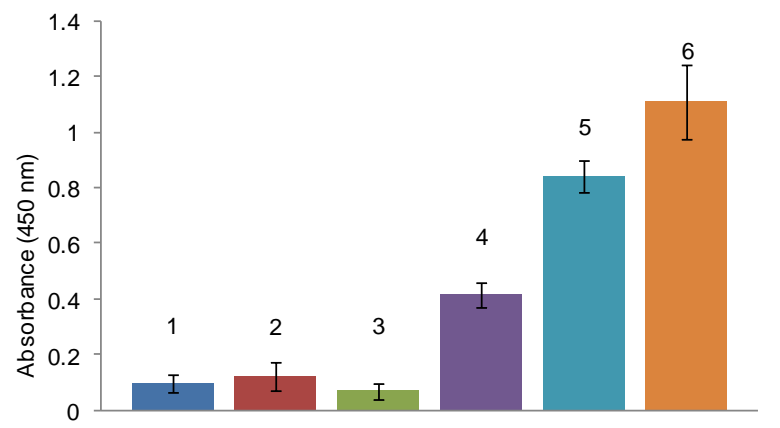

Figure 2. Enzyme-linked lectin assay absorbance at $450 \mathrm{~nm}$ of the supernatant after o-phenylenediamine $/ \mathrm{H}_{2} \mathrm{O}_{2}$ treatment: of $0.1 \mathrm{~mL}$ of 1 ) Maleimide-activated Sepharose with $10 \mu \mathrm{g}$ ConA-HRP 2) Maltose-modified Sepharose with $10 \mu \mathrm{g}$
peanut-HRP (PNA), 3-6) Maltose-modified Sepharose with $0 \mu \mathrm{g}(3), 5 \mu \mathrm{g}(4)$ $10 \mu \mathrm{g}(5)$ and $20 \mu \mathrm{g}(6)$ of ConA-HRP

To further characterize the maltose-modified Sepharose adsorbent, we examined its specificity for Concanavalin $A$ (ConA) lectin in an enzyme-linked lectin assay (Figure 2) ${ }^{\left[{ }^{[3]}\right]}$ As one would expect, the binding of horseradish peroxydase-ConA conjugate (ConA-HRP) onto the maltose-functionalized adsorbent showed a dose-dependent response. To confirm that the adsorption of ConA was not resulting from a non-specific interaction with the support, a control experiment was performed with maleimideactivated Sepharose particles. No colorimetric response was observed when incubating ConA with the non-glycosylated Sepharose particles thus attesting of the absence of non-specific binding. The specificity of maltose-modified Sepharose toward ConA was also further confirmed by the absence of color development upon incubation with HRP-conjugated Arachis hypogaea (peanut) lectin (PNA-HRP) a galactose-binding protein. These findings prompted us to evaluate the maltose-modified Sepharose particles as a matrix for lectin affinity chromatography. Gel capacity was calculated by saturating maltose-modified Sepharose particles ( $1 \mathrm{~mL}, 50 \%$ vol. slurry) with ConA ( $5 \mathrm{mg})$ and after washing with PBS, eluting the lectin with a $0.2 \mathrm{M}$ solution of free maltose. The protein content in the eluted fraction was determined using the Bradford assay. The gel showed a binding capacity of $2 \mathrm{mg}$ of ConA lectin per milliliter resin. The same column was then incubated with a mixture composed of $1.5 \mathrm{mg}$ of ConA and $3 \mathrm{mg}$ of BSA for $1 \mathrm{~h}$ (Figure 3). After washing with PBS buffer until no protein was detectable in the eluate, the lectin was desorbed with a $0.2 \mathrm{M}$ solution of maltose and quantified using a Bradford assay. According to the titration, $84 \%$ of ConA was recovered. The composition of the different fractions was analyzed by SDS-PAGE electrophoresis (Figure 4). As expected, the wash fractions contained BSA and little or no ConA was detected, confirming its strong and specific interaction on the matrix. Moreover, the electrophoretic bands in lanes 5 and 6 show only ConA (Figure 4) without any contaminant thus attesting to successful separation.

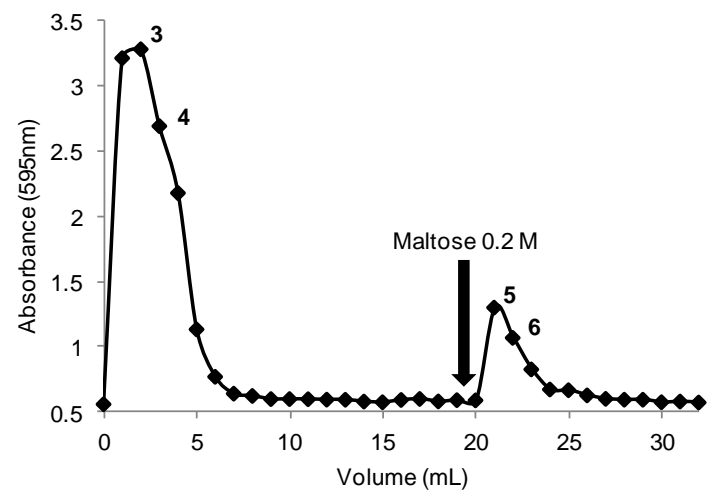

Figure 3. Purification of a 1:2 ConA:BSA mixture $(w / w)$ on a maltose-modified Sepharose. 


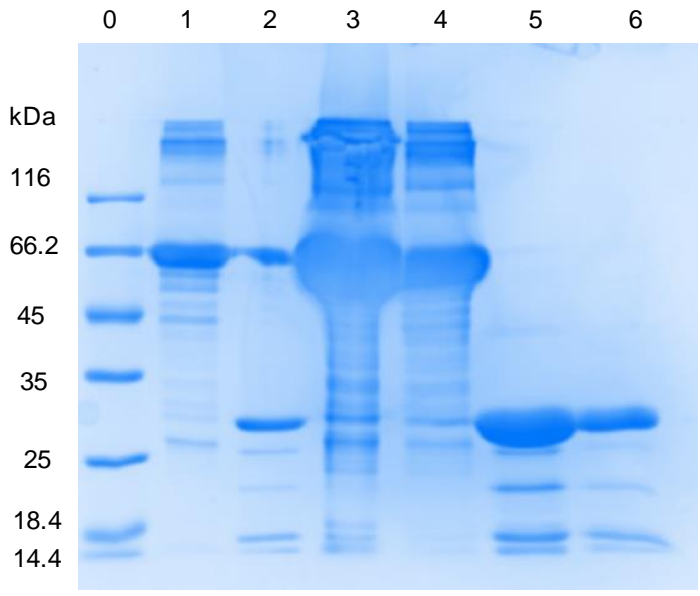

Figure 4. SDS-PAGE of ConA/BSA Purification, lane 0) size marker, lane 1) BSA, lane 2) ConA standard, lanes 3,4,5,6) fractions 3-6.

These results obtained with maltose clearly demonstrate that the Diels-Alder reaction is a straightforward and efficient method for conjugating carbohydrates to Sepharose particles. Furthermore, the Sepharose-supported carbohydrate was readily accessible for protein binding with an enzyme and a lectin.

Encouraged by these results, we adapted this process to the preparation of novel immunosorbents for serum purification by immobilization of the $\mathrm{A}, \mathrm{B}$ and $\mathrm{H}$ glycan blood group antigens on Sepharose particles. The glycans were produced by bacterial synthesis in metabolically engineered $E$. coli cells ${ }^{[25,26]}$ and chemically modified with a furfuryl group as described above. Again, the anomeric functionalization occurred in high yields despite the more complex structure of the glycans. The furyl glycoconjugates 2, 3 and $\mathbf{4}$ were isolated in $88 \%, 78 \%$ and $90 \%$ yield respectively after purification by flash chromatography on silica gel. A Diels-Alder reaction with furyl conjugates 2, 3 and 4 and maleimide-activated Sepharose afforded neoglyconjugates which were evaluated for protein binding with Ulex europaeus agglutinin (UEA lectin), anti-A and anti-B antibodies for the $\mathrm{H}, \mathrm{A}$ and $B$ antigens, respectively. Anti- $\mathrm{H}$ monoclonal antibodies are not present in $\mathrm{ABO}$ blood groups, except for the rare Bombay phenotype ${ }^{[36]}$ thus UEA lectin was used to probe the $\mathrm{H}$-antigen matrix. UEA was labeled with the CF-488 ${ }^{\mathrm{TM}}$ fluorescent staining kit according to the procedure indicated by the manufacturer and was used directly without any particular purification. As expected, UEA lectin did not show any affinity for the control maltosemodified Sepharose particles, but it was efficiently adsorbed onto the $\mathrm{H}$ antigen-modified Sepharose and then specifically eluted by a $0.2 \mathrm{M}$ solution of free $\mathrm{H}$-antigen trisaccharide i.e 2'-fucosyl lactose (see Supporting Information). The affinity of the $A$ and $B$ blood group antigen-modified adsorbents was then assessed by fluorescence microcopy. Monoclonal anti-blood group A and B antibodies were obtained from Sigma-Aldrich as culture supernatants. Since the discrimination between mAbs is not possible by electrophoresis, they were labeled with two distinct fluorophores: CF-488 ${ }^{\mathrm{TM}}$ (green) and CF-568 ${ }^{\mathrm{TM}}$ (red) dyes for the anti-A and anti-B antibodies, respectively. The blood group adsorbents were individually incubated with the corresponding $\mathrm{mAb}$, rinsed and observed under fluorescence microscopy. As shown in Figure 5B, the antigen A-modified Sepharose particles were coated with a strong green fluorescence after being in contact with anti-A mAb, but the control maltose-modified particles remained unlabeled under the same conditions.
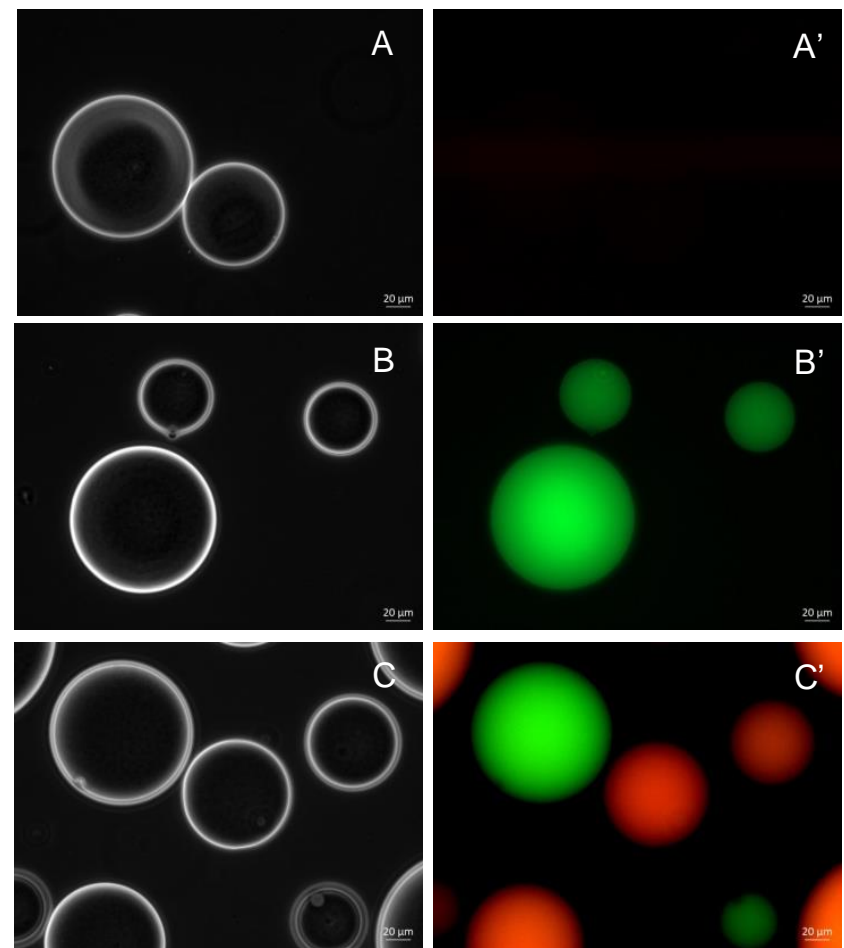

Figure 5. Microscopy image (20x) of maltose-modified Sepharose particles incubated with anti-A mAb: under bright field $(A)$, with FITC filter ( $\left.A^{\prime}\right)$, Antigen A-modified Sepharose particles incubated with anti-A mAb under bright field $(B)$, with FITC filter (B'), mixture of antigen A and B-modified Sepharose particles incubated with anti-A and anti-B mAbs under bright field (C), and with FITC filter and DS-red filter (C')

These results once again confirm that the carbohydrate epitope on the solid matrix is available for protein binding and also that the interaction is highly specific, which is an important feature for potential medical applications. Anti-B antibodies were similarly specifically adsorbed onto the antigen B-modified Sepharose particles (see Supporting Information). Finally, Figure 5C shows a mixture of anti-A and anti-B labeled antibodies after simultaneous incubation with antigen A-modified particles and antigen B-modified particles. Despite the high structural analogy between $A$ and $B$ antigens, which differ only by an $\mathrm{N}$-acetyl moiety on the terminal sugar, no cross-reactivity occurred and each antibody selectively recognized its corresponding antigen. 


\section{Conclusions}

In conclusion, we developed a rapid, high-yielding method for the anomeric functionalization of complex carbohydrates by introducing a furfuryl group and avoiding tedious protecting-group chemistry. The resulting glycoconjugates were immobilized very efficiently on a solid Sepharose matrix via a Diels-Alder cycloaddition in water and in the absence of any catalyst. This method therefore constitutes an interesting alternative to CuAAC click chemistry. Furthermore, any valuable, unreacted oligosaccharides can be recovered unaltered after ligation. The glycan-modified Sepharose particles were then assessed as affinity adsorbents for carbohydrate-binding proteins. Lectins were purified with high efficiency and great ease, opening new prospects for high-throughput protein screening. Additionally, anti-blood group A and B antibodies were specifically captured onto Sepharose particles conjugated with their respective antigens. Exciting applications of these immunosorbents include the preparation of antibody-free universal blood plasma. Expanding this approach to other glycan antigens may also offer new opportunities for the treatment of autoimmune diseases such as the Guillain-Barré syndrome. Finally, this robust and versatile bioconjugation approach should also benefit other fields of applications such as the development of nanocarriers for drug delivery or the stabilization of therapeutic proteins among others because of the growing interest of oligosaccharides in these areas.

\section{Experimental Section}

Materials: NHS-activated Sepharose 4B Fast flow GE Healthcare, furfurylamine, maleic anhydride, acetic anhydride; ethylene diamine, ethanolamine, di-tert-butyl dicarbonate, Mix-n-Stain ${ }^{\text {TM }}$ CF ${ }^{\text {TM }}$ 488A, Mix-nStain ${ }^{\text {TM }}$ CF ${ }^{\text {TM }} 568$ antibody labeling kit were purchased from Sigma-Aldrich and used as received. Native and HRP-conjugated lectins (Ulex europaeus UEA-I, Concanavalin A from Canavalia ensiformis and Arachis hypogaea agglutinin PNA) were purchased from Sigma-Aldrich Amyloglucosylase AM-G2 from Aspergillus Niger was generously provided by Prof. Birte Svensson ${ }^{[34]}$. Monoclonal anti-blood group A and anti-blood group $B$ antibodies produced in mouse were purchased from SigmaAldrich as culture supernatant and the buffer was exchanged to PBS using Centricon ${ }^{\mathrm{TM}} 10 \mathrm{kDa}$ centrifugal filtration units prior to use. Maltose hydrate was purchased from Sigma-Aldrich and lyophilized prior to use. All solvents were purchased from Carlos Erba and were used without prior purification. $\quad \mathrm{N}$-tert-Butoxycarbonyl-ethylenediamine, $\mathrm{N}$-(2-((tertButoxycarbonyl)amino)ethyl)maleimide, and $\mathrm{N}$-(2-Aminoethyl)maleimide hydrochloride were synthesized according to literature. ${ }^{[27]}$ Protein were titrated with BioRad coomassie-blue assay by mixing the diluted dye with 5 volumes of the protein solution, vortexing, incubating the sample 10min and reading the absorbance at $595 \mathrm{~nm}$. Protein sample were denatured by dissolving in TRIS $\mathrm{HCl}(0.1 \mathrm{M}), 20 \%$ Glycerol, $5 \%$ sodium dodecyl sulfate, $5 \%$ dithiothreitol and boiled for $5 \mathrm{~min}$. Electrophoresis was carried on SDSPAGE $12 \%$ at $35 \mathrm{~mA}$ for one hour prior staining with coomassie blue.

Equipments: Proton and Carbon nuclear magnetic resonance (HNMR) analyses were recorded at $25^{\circ} \mathrm{C}$ on a Bruker Advance DRX400 spectrometer. ${ }^{[37]}$ Chemical shifts $(\delta)$ are given in ppm. The solvent residual peak of $\mathrm{D}_{2} \mathrm{O}$ was used as internal standards and calibrated at $4.75 \mathrm{ppm}$. Matrix-assisted laser desorption ionization time-of-flight (MALDI-TOF) measurements were performed on a Bruker Daltonics Autoflex apparatus using 2,5-dihydroxybenzoic acid (DHB) as a matrix. High resolution mass spectrometry was carried on a Waters Xevo ${ }^{\text {TM }}$ G2-S QTOF (quadrupole hybrid with orthogonal acceleration time-of-flight) mass spectrometer apparatus. Fluorescence experiments were carried out on a Perkin Elmer LS-50B spectrometer with a pulsed high pressure xenon source using Hellma® Analytics suprasil quartz cuvettes. Fluorescence microscopy images were taken with a Zeiss Axio Vert.A1 epifluorescence microscope using either a FITC or DS-red filter. UV-visible measurements were carried out on a Varian® Carry 50 Bio spectrometer.

\section{Synthesis of furyl glycoconjugates}

General procedure for the synthesis of $\boldsymbol{N}$-acetamido- $\boldsymbol{N}$-furfuryl modified oligosaccharides: Lyophilized oligosaccharide was dissolved in the smallest volume of furfurylamine possible to get a homogeneous solution and the reaction mixture was stirred for $72 \mathrm{~h}$ at $25^{\circ} \mathrm{C}$. The solution was concentrated and co-evaporated with toluene. The crude glycosylamine was then dissolved in methanol (typically at $1 \mathrm{~g} / 10 \mathrm{~mL}$ ) and acetic anhydride $(50 \% \mathrm{~V} / \mathrm{V})$ was slowly added at $0^{\circ} \mathrm{C}$ to the solution. The reaction mixture is then allowed to warm up to room temperature and stirred a further $16 \mathrm{~h}$. The solution was then concentrated and coevaporated with toluene. The residue was dissolved in $14 \%$ aqueous ammonia, stirred $1 \mathrm{~h}$ at room temperature to hydrolyse potential $O$-acetyl groups. After concentration of the solution to half of its initial volume under vacuum, the aqueous phase was extracted 3 times with ethyl acetate to remove any free $N$-acetyl furfurylamine and freeze dried. Crude $N$ acetamido- $N$-furfuryl-carbohydrates displayed satisfactory purity as judged by ${ }^{1} \mathrm{H}$ NMR (see Supporting Information). However, a purification by flash chromatography on silica gel $\left(\mathrm{CH}_{3} \mathrm{CN} / \mathrm{H}_{2} \mathrm{O} 9: 1\right.$ to $\left.8: 2 \mathrm{v} / \mathrm{v}\right)$ was carried out for complete characterization prior to grafting onto the Sepharose particles.

Maltosyl- $N$-acetamido- $N$-furfurylamine (1): Maltosyl- $N$-acetamido- $N$ furfurylamine 1 was isolated in $84 \%$ yield $(11.3 \mathrm{~g})$ after purification. The reaction was conducted with $10 \mathrm{~g}$ of maltose in $20 \mathrm{~mL}$ of furfurylamine. Acetylation was carried out in $100 \mathrm{~mL}$ of methanol in presence of $50 \mathrm{~mL}$ of acetic anhydride. ${ }^{1} \mathrm{H}$ NMR $\left(400 \mathrm{MHz}, \mathrm{D}_{2} \mathrm{O}\right) \delta 7.49-7.43(\mathrm{~m}, 1 \mathrm{H},-\mathrm{O}-\mathrm{CH}=\mathrm{CH}$ rotamers), 6.44-6.34 (m, $2 \mathrm{H},-\mathrm{O}-\mathrm{CH}=\mathrm{CH}$ - rotamers ), $5.51(\mathrm{~d}, 0.4 \mathrm{H}, J=9.0$ $\mathrm{Hz}, \mathrm{H}_{1}{ }^{\mathrm{Glc}-1}$ rotamers), $5.42\left(\mathrm{~m}, 1 \mathrm{H}, \mathrm{H}_{1} \mathrm{Glc}-\mathrm{II}\right), 5.09\left(\mathrm{~d}, 0.6 \mathrm{H}, J=9.0 \mathrm{~Hz}, \mathrm{H}_{1} \mathrm{Glc}\right.$ ${ }_{1}$ rotamers), 4.69-4.53 (m, $\left.2 \mathrm{H},-\mathrm{CH}_{2} \mathrm{NAc}\right), 3.89-3.39\left(\mathrm{~m}, 12 \mathrm{H}, \mathrm{H}_{2}{ }^{\mathrm{Glc} \mathrm{I}-\mathrm{II}}-\mathrm{H}_{5}{ }^{\mathrm{Glc}}\right.$ $\left.{ }^{\mathrm{I}-\mathrm{II}}\right), 2.29-2.24\left(2 \mathrm{~s}, 3 \mathrm{H}, \mathrm{NCOCH} \mathrm{H}_{3}\right.$ rotamers); ${ }^{13} \mathrm{C} \mathrm{NMR}\left(100 \mathrm{MHz}, \mathrm{D}_{2} \mathrm{O}\right) \delta$ 176.56, 175.35, 151.16, 150.59, 142.84, 142.16, 110.69, 108.55, 108.22, $99.58,86.65,82.47,77.24,76.94,76.66,76.49,76.15,76.01,72.85,72.72$, 71.71, 71.67, 70.24, 69.71, 69.33, 60.73, 60.65, 60.48, 40.91, 37.47, 21.86, 21.27; ESI-HRMS: $m / z$ calcd for $\mathrm{C}_{19} \mathrm{H}_{29} \mathrm{NO}_{12}[\mathrm{M}+\mathrm{Na}]^{+} 486.1588$, found 486.1584 .

Fuc- $\alpha(1-2)-G a l-\beta(1-4)-G l c-\beta-N$-acetamido- $N$-furfurylamine $\quad$ (Blood group $H$ antigen) (2): Furyl-modified blood group $H$ antigen oligosaccharide 2 was isolated in $88 \%$ yield $(1.1 \mathrm{~g})$ after purification. The reaction was conducted with $1 \mathrm{~g}$ of 2'-fucosyl lactose in $2 \mathrm{~mL}$ of furfurylamine. Acetylation was carried out in $10 \mathrm{~mL}$ of methanol in presence of $5 \mathrm{~mL}$ of acetic anhydride. ${ }^{1} \mathrm{H}$ NMR $\left(400 \mathrm{MHz}, \mathrm{D}_{2} \mathrm{O}\right) \delta 7.49$ $7.43(\mathrm{~m}, 1 \mathrm{H},-\mathrm{O}-\mathrm{CH}=\mathrm{CH}$ rotamers $), 6.44-6.34(\mathrm{~m}, 2 \mathrm{H},-\mathrm{O}-\mathrm{CH}=\mathrm{CH}-$ rotamers), 5.49 (d, $0.4 \mathrm{H}, J=9.0 \mathrm{~Hz}, \mathrm{H}_{1}$ Glc rotamers), $5.31\left(\mathrm{~m}, 1 \mathrm{H}, \mathrm{H}_{1}\right.$ Fuc $)$, $5.04\left(\mathrm{~d}, 0.6 \mathrm{H}, J=9.0 \mathrm{~Hz}, \mathrm{H}_{1}\right.$ Glc rotamers $), 4.69-4.52\left(\mathrm{~m}, 3 \mathrm{H}, \mathrm{H}_{1}\right.$ Gal, $\left.\mathrm{CH}_{2} \mathrm{NAc}\right), 4.22(\mathrm{~m}, 1 \mathrm{H}), 3.94-3.51(\mathrm{~m}, 15 \mathrm{H}), 2.29-2.24\left(2 \mathrm{~s}, 3 \mathrm{H}, \mathrm{NCOCH}_{3}\right.$ rotamers), $1.23\left(\mathrm{~d}, 3 \mathrm{H}, J=6.6 \mathrm{~Hz}, \mathrm{Me}^{\mathrm{Fuc}}\right) ;{ }^{13} \mathrm{C} \mathrm{NMR}\left(100 \mathrm{MHz}, \mathrm{D}_{2} \mathrm{O}\right) \delta$ $176.66,175.30,151.13,150.55,142.86,142.17,110.69,108.57,108.23$, $100.33,100.23,99.36,86.87,82.60,77.40,77.32,76.35,76.23,75.37$, $75.31,75.26,75.13,74.94,73.60,71.68,70.26,69.63,69.18,68.22,68.18$, $66.98,66.95,61.19,60.14,60.01,40.95,37.55,21.85,21.26,15.34$, 
15.28; ESI-HRMS: $m / z$ calcd for $\mathrm{C}_{25} \mathrm{H}_{39} \mathrm{NO}_{16}[\mathrm{M}+\mathrm{Na}]^{+} 632.2167$, found 632.2157

\section{GaINAc- $\alpha(1-3)$-[Fuc- $\alpha(1-2)]-G a l-\beta(1-4)$ Glc- $\beta$ - $N$-acetamido- $N$ -}

furfurylamine (Blood group A antigen) (3): Furyl-modified blood group A antigen oligosaccharide 3 was isolated in $78 \%$ yield $(21 \mathrm{mg})$ after purification. The reaction was conducted with $23 \mathrm{mg}$ of blood group A antigen oligosaccharide in $0.5 \mathrm{~mL}$ of furfurylamine. Acetylation was carried out in $1 \mathrm{~mL}$ of methanol in presence of $0.5 \mathrm{~mL}$ of acetic anhydride. ${ }^{1} \mathrm{H} \mathrm{NMR}$ $\left(400 \mathrm{MHz}, \mathrm{D}_{2} \mathrm{O}\right) \delta$ 7.49-7.43 (m, $1 \mathrm{H},-\mathrm{O}-\mathrm{CH}=\mathrm{CH}$ rotamers), 6.44-6.34 (m, $2 \mathrm{H},-\mathrm{O}-\mathrm{CH}=\mathrm{CH}$ - rotamers), 5.49 (d, $0.4 \mathrm{H}, J=9.0 \mathrm{~Hz}, \mathrm{H}_{1}$ Glc rotamers), 5.35 (m, $1 \mathrm{H}, \mathrm{H}_{1}$ Fuc $), 5.17$ (d, $1 \mathrm{H}, J=3.7 \mathrm{~Hz}, \mathrm{H}_{1}$ GalNAc), $5.02(\mathrm{~d}, 0.6 \mathrm{H}, J=9.0 \mathrm{~Hz}$, $\mathrm{H}_{1} \mathrm{Glc}$ rotamers), 4.66-4.55 (m, 3H, $\left.\mathrm{H}_{1} \mathrm{Gal},-\mathrm{CH}_{2} \mathrm{NAc}\right), 4.34-4.18(\mathrm{~m}, 4 \mathrm{H})$, 3.99-3.50 (m, 18H), 2.29-2.24 (2s, 3H, NCOCH $\mathrm{N}_{3}$ rotamers), $2.03(\mathrm{~s}, 3 \mathrm{H}$, $\left.\mathrm{NHCOCH}_{3}{ }^{\text {GalNAc}}\right) 1.25$ (d, 3H, $\left.J=6.6 \mathrm{~Hz}, \mathrm{Me}^{\mathrm{Fuc}}\right) ;{ }^{13} \mathrm{C} \mathrm{NMR}\left(400 \mathrm{MHz}, \mathrm{D}_{2} \mathrm{O}\right)$ $\delta 176.69,175.29,174.84,151.12,150.55,142.86,142.18,110.69,108.56$, $108.23,100.15,100.06,98.61,98.55,91.35,86.91,82.55,77.46,77.40$, $75.76,75.49,75.37,75.24,75.03,72.34,72.24,71.70,71.12,70.30,69.95$ $69.65,68.50,67.81,67.68,66.93,63.11,61.33,61.26,60.14,60.00,49.51$ 40.88, 37.54, 21.97, 21.83, 21.27, 15.19, 15.13; ESI-HRMS: $\mathrm{m} / \mathrm{z}$ calcd for $\mathrm{C}_{33} \mathrm{H}_{52} \mathrm{~N}_{2} \mathrm{O}_{21}[\mathrm{M}+\mathrm{Na}]^{+} 835.2960$, found 835.2941 .

Gal- $\alpha$ (1-3)-[Fuc- $\alpha(1-2)]-G a l-\beta(1-4)$ Glc- $\beta-N$-acetamido- $N$-furfurylamine (Blood group $B$ antigen) (4): Furyl-modified blood group $B$ antigen oligosaccharide 4 was isolated in $90 \%$ yield $(22 \mathrm{mg})$ after purification. The reaction was conducted with $21 \mathrm{mg}$ of blood group $B$ antigen in $0.5 \mathrm{~mL}$ of furfurylamine. Acetylation was carried out in $1 \mathrm{~mL}$ of methanol in presence of $0.5 \mathrm{~mL}$ of acetic anhydride. ${ }^{1} \mathrm{H} \mathrm{NMR}\left(400 \mathrm{MHz}, \mathrm{D}_{2} \mathrm{O}\right) \delta 7.49-7.43(\mathrm{~m}$ $1 \mathrm{H},-\mathrm{O}-\mathrm{CH}=\mathrm{CH}$ rotamers $), 6.44-6.34(\mathrm{~m}, 2 \mathrm{H},-\mathrm{O}-\mathrm{CH}=\mathrm{CH}$ - rotamers $), 5.49$ (d, $0.4 \mathrm{H}, J=9.0 \mathrm{~Hz}, \mathrm{H}_{1} \mathrm{Glc}$ rotamers), 5.34-5.24 (m, $2 \mathrm{H}, \mathrm{H}_{1} \mathrm{Fuc}, \mathrm{H}_{1} \mathrm{Gal}$ ), 5.03 (d, $0.6 \mathrm{H}, J=9.0 \mathrm{~Hz}, \mathrm{H}_{1} \mathrm{Glc}$ rotamers), 4.69-4.54 (m, 3H, $\mathrm{H}_{1}$ Gal, $-\mathrm{CH}_{2} \mathrm{NAc}$ ), 4.32-4.17 (m, 3H), 4.00-3.49 (m, 19H), 2.29-2.24 (2s, 3H, NCOCH rotamers), 1.25 (d, $\left.3 \mathrm{H}, J=6.6 \mathrm{~Hz}, \mathrm{Me}^{\mathrm{Fuc}}\right) ;{ }^{13} \mathrm{C} \mathrm{NMR}\left(400 \mathrm{MHz}, \mathrm{D}_{2} \mathrm{O}\right) \delta$ $176.68,175.29,151.12,150.55,142.86,142.18,110.69,108.56,108.23$, $100.20,100.11,98.70,93.08,86.94,82.56,77.43,77.38,76.30,75.49$, $75.33,75.20,75.01,72.47,72.39,71.70,71.18,70.28,70.00,69.62,69.52$ $69.28,68.07,67.70,66.87,63.58,61.28,61.22,60.14,60.00,40.89,37.54$ 21.84, 21.26, 15.19, 15.13; ESI-HRMS: $m / z$ calcd for $\mathrm{C}_{31} \mathrm{H}_{49} \mathrm{NO}_{21}[\mathrm{M}+\mathrm{Na}]^{+}$ 794.2694 , found 794.2692 .

\section{Synthesis of oligosaccharide-modified Sepharose particles}

Maleimide-activated Sepharose 4B: NHS-activated Sepharose 4B particles ( $10 \mathrm{~mL}$ of commercially available GE Healthcare, $50 \%$ vol. slurry in isopropanol, $0.110 \mathrm{mmol}$ NHS-ester) were pipetted in a Biorad PolyPrep $\AA$ column and washed four times at $4^{\circ} \mathrm{C}$ with $0.01 \mathrm{M} \mathrm{HCl}(10 \mathrm{~mL})$. The particles were then rinsed at $4^{\circ} \mathrm{C}$ with $0.1 \mathrm{M} \mathrm{AcONa}$ buffered solution $\mathrm{pH}$ $8.5(5 \mathrm{~mL})$ then $\mathrm{N}$-(2-aminoethyl)maleimide hydrochloride ${ }^{[26]}(0.55 \mathrm{mmol}$, 5 equiv.) were added in $5 \mathrm{~mL}$ of the same acetate buffer. After $4 \mathrm{~h}$ in a rotary stirrer the particles were washed with water $(10 \mathrm{~mL})$ then briefly with $0.1 \mathrm{M} \mathrm{NaOH}(5 \mathrm{~mL})$ at $4^{\circ} \mathrm{C}$ to hydrolyze any unreacted $\mathrm{NHS}$ ester. The resin was then soaked in water with $0.1 \%$ sodium azide and stored at $4^{\circ} \mathrm{C}$ IR $\left(\mathrm{cm}^{-1}\right)$ : 3448 (str,broad), 2938 (med), 1816 (wk, sharp), 1710 (str, sharp), 1636 (med, amide), 1560 (sml, sharp), 1380 (med, sharp), 1078 (str, med), 928 (med, sharp).

The coupling reaction reached $85 \%$ conversion as determined by the quantification of the remaining carboxylic acid groups on the maleimideactivated particles as compared to those of hydrolyzed NHS-Sepharose 4B. Briefly, $1 \mathrm{~mL}$ of particles is transferred to a titration vessel and the solution is made acidic by addition of $0.01 \mathrm{M} \mathrm{HCl}(5 \mathrm{~mL})$ and stirred for an hour. The solution is then titrated with $0.01 \mathrm{M} \mathrm{NaOH}$ and the volume is plotted against the conductometry of the solution. The result obtained with maleimide-activated Sepharose 4B particles was compared against hydrolyzed NHS-Sepharose 4B as indicator of the total acid content.

Oligosaccharide-modified Sepharose 4B: Maleimide-activated Sepharose 4B resin $(2 \mathrm{~mL}, 50 \%$ vol. slurry in water, $0.025 \mathrm{mmol})$ was pipetted in a Biorad Poly-Prep $\AA$ column and be rinsed four times with $1 \mathrm{~mL}$ water. Furyl-modified oligosaccharide $(1.25 \mathrm{mmol}, 5$ equiv.) was then added in $1 \mathrm{~mL}$ water. After $16 \mathrm{~h}$ in a rotary stirrer at $40^{\circ} \mathrm{C}$ the particles are rinsed with $10 \mathrm{~mL}$ of water. The resin is then stored in water with $0.1 \%$ sodium azide.

The ligation efficiency reached $85 \%$ conversion. The yield was determined by quantification of glucose released from the maltose-modified Sepharose particles after enzymatic treatment with a glucoamylase. Briefly, maltose-modified Sepharose particles $(0.2 \mathrm{~mL}, 50 \%$ vol slurry in water $)$ were placed in a Biorad Poly-Prep $\AA$ column, rinsed 4 times with $0.1 \mathrm{M}$ acetate buffer $(\mathrm{pH} 5)$ and incubated with a large excess of Glucoamylase

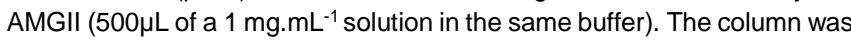
stirred $12 \mathrm{~h}$ at $37^{\circ} \mathrm{C}$. The amount of glucose in the supernatant was determined by the BCA reducing sugar assay.

\section{Protein binding and purification}

Enzyme Linked Lectin Assay (ELLA) with Concanavalin A lectin on maltose-modified Sepharose particles: Carbohydrate-modified particles $\left(0.2 \mathrm{ml}, 50 \%\right.$ vol slurry in water) were placed in Biorad Poly-Prep ${ }^{\circledR}$ column tubes and rinsed with TBS buffer (TRIS $10 \mathrm{mM}, \mathrm{pH}$ 7.6, $15 \mathrm{mM}$ $\mathrm{NaCl}, 1 \mathrm{mM} \mathrm{Ca}^{2+}, 1 \mathrm{mM} \mathrm{Mg}^{2+}$ ) containing $3 w t \%$ bovine serum albumin (BSA). The particles were let to soak in $500 \mu \mathrm{L}$ of that same buffer for 10 min to block any non-specific binding site. Particles were then washed with TBS containing $0.3 \%$ BSA. The particles are then soaked in $0.5 \mathrm{~mL}$ of fresh buffer containing a known amount of HRP conjugated lectin and incubated $1 \mathrm{~h}$ at $37^{\circ} \mathrm{C}$. The particles were thoroughly washed with TBS buffer and then transferred to $0.4 \mathrm{~mL}$ of deionized water prior to add $200 \mu \mathrm{L}$ of OPDsigmafast $^{\mathrm{TM}}$ solution. After $10 \mathrm{~min}$ the overhead solution is transferred to $1 \mathrm{~mL}$ cuvettes and the absorbance was measured at $450 \mathrm{nM}$.

Concanavalin $A$ purification on maltose-modified Sepharose particles: Maltose-modified particles ( $1 \mathrm{ml}, 50 \%$ vol. slurry in water) were placed in Biorad Poly-Prep $\AA$ column tubes and rinsed with PBS buffer (10 $\mathrm{mM}, \mathrm{pH} 6.8,15 \mathrm{mM} \mathrm{NaCl}, 1 \mathrm{mM} \mathrm{Ca}^{2+}, 1 \mathrm{mM} \mathrm{Mg}^{2+}$ ). The particles are then soaked in $2 \mathrm{~mL}$ of fresh buffer containing $1 \mathrm{mg}$ of Concanavalin $A$ and 3 $\mathrm{mg}$ of bovine serum albumin and then incubated $1 \mathrm{~h}$ at $37^{\circ} \mathrm{C}$. The particles were rinsed with PBS and $1 \mathrm{~mL}$ fractions were collected for 50 column volumes. The buffer was then swapped for a $0.2 \mathrm{M}$ maltose solution in PBS and the fractions collected. Each fraction was then titrated for protein content using the Bradford assay. Two fractions of each peak were then analyzed by electrophoresis on SDS-PAGE.

Ulex Europaeus lectin purification on $\mathrm{H}$ antigen-modified Sepharose particles: Blood group $\mathrm{H}$ antigen-modified Sepharose particles $(1 \mathrm{ml}$, $50 \%$ vol. slurry in water) were placed in Biorad Poly-Prep $\AA$ column tubes and rinsed with TRIS buffer ( $10 \mathrm{mM}, \mathrm{pH} 7.6,15 \mathrm{mM} \mathrm{NaCl})$. The particles are then soaked in $2 \mathrm{~mL}$ of fresh buffer containing $100 \mu \mathrm{g}$ of CF488A ${ }^{\mathrm{TM}}$ fluorescent-tagged Ulex Europaeus lectin and incubated $1 \mathrm{~h}$ at $37^{\circ} \mathrm{C}$. The particles were rinsed with TBS and $1 \mathrm{~mL}$ fractions were collected for 20 column volumes. The buffer was then swapped for a $0.2 \mathrm{M}$ solution of 2'fucosyl-lactose in TBS and the fractions collected. The fluorescence of each fraction was measured at $515 \mathrm{~nm}$ with excitation at $488 \mathrm{~nm}$. The same protocol was applied to maltose modified particles for a control experiment. 
Adsorption of anti-blood group A and B antibodies on blood goup A antigen-modified Sepharose particles and blood goup $B$ antigenmodified Sepharose particles respectively: Monoclonal anti-blood group $A$ and $B$ antibodies produced in mouse were fluorescent-tagged using Mix-n-Stain ${ }^{{ }^{M}}$ CF $^{{ }^{T M}}$ 488A antibody labeling kit and Mix-n-Stain ${ }^{\mathrm{TM}}$ $\mathrm{CF}^{\mathrm{TM}} 568$ antibody labeling kit respectively. Blood group $A$ antigenmodified Sepharose particles $(0.2 \mathrm{ml}, 50 \%$ vol. slurry in water $)$ were placed in Biorad Poly-Prep $\AA$ column tubes and rinsed with TRIS buffer $(50 \mathrm{mM}$, $\mathrm{pH} 7.8,150 \mathrm{mM} \mathrm{NaCl}$ ) at $4^{\circ} \mathrm{C}$. The particles are then soaked in $200 \mu \mathrm{L}$ of fresh buffer containing $50 \mu \mathrm{L}$ of CF488A ${ }^{\mathrm{TM}}$ fluorescent-tagged anti-blood group $A$ antibodies and incubated $1 \mathrm{~h}$ at $4^{\circ} \mathrm{C}$. The particles were rinsed with $5 \mathrm{~mL}$ TBS then the particles were pipetted onto a glass slide and observed on an epifluorescence microscope. The same protocol was applied to Blood group B antigen-modified Sepharose particles. Maltose-modified Sepharose particles were treated with the same protocol as a control experiment.

\section{Acknowledgements}

The authors thank the MENRT for the PhD fellowship to A. Petrelli as well as the CNRS, the Mass spectrometry and NMR platform of ICMG, Carnot Institut Polynat and Labex Arcane (ANR-11LABX-0003-01). Prof. B. Svensson is acknowledged for her generous gift of amyloglucosylase G2.

Keywords: Bioconjugation • Click Chemistry • Carbohydrates • Affinity adsorbent $\bullet$ Lectins/Immunoglobulins

[1] G. W. Hart, R. J. Copeland, Cell 2010, 143, 672-676

[2] C. Orgeret, E. Seillier, C. Gautier, J. Defaye, H. Driguez, Carbohydr. Res. 1992, 224, 29-40.

[3] Lectins Methods and Protocols, Vol. 1200, Humana Press, 2014

[4] a) E. Kaltgrad, S. Sen Gupta, S. Punna, C.-Y. Huang, A. Chang, C.-H. Wong, M. G. Finn, O. Blixt, ChemBioChem 2007, 8, 1455-1462; b) T. Pochechueva, A. Chinarev, M. Spengler, E. Korchagina, V. Heinzelmann-Schwarz, N. Bovin, R. Rieben, Analyst 2011, 136, 560-569.

[5] K. Townson, J. Boffey, D. Nicholl, J. Veitch, D. Bundle, P. Zhang, E. Samain, T. Antoine, A. Bernardi, D. Arosio, S. Sonnino, N. Isaacs, H. J. Willison Glycobiology, 2007, 17(3), 294-303.

[6] L. Rydberg, A. Bengtsson, O. Samuelsson, K. Nilsson, M. Breimer, Transplant. Int. 2005, 17, 666-672.

[7] a) L. Lindberg, K. Theinert, J. Liu, J. Holgersson, Transfusion 2012, 52 2356-2367. b) M. Yazer, A. F. Eder, K. J. Land, Transfusion 2013, 53 1627-1633.

[8] T. Antoine, B. Priem, A. Heyraud, L. Greffe, M. Gilbert, W. W. Wakarchuk, J. S. Lam, E. Samain, ChemBioChem 2003, 4, 406-412.

[9] T. Antoine, C. Bosso, A. Heyraud, E. Samain, Biochimie 2005, 87, 197203.

[10] C. Dumon, C. Bosso, J. P. Utille, A. Heyraud, E. Samain, ChemBioChem 2006, 7, 359-365.

[11] G. S. Murthy, N. R. Moudgal, J. Biosci. 1986, 10, 351-358.

[12] D. Pepper, in Practical Protein Chromatography, Vol. 11 (Eds.: A. Kenney, S. Fowell), Humana Press, 1992, pp. 173-196.

[13] V. Lavanya Latha, K. A. Kulkarni, R. Nagender Rao, N. Siva Kumar, K. Suguna, Acta Crystallogr. F2006, 62, 163-165.

[14] M. Isamu, K. Haruko, A. Yumiko, I. Yuki, S. Nobuko, Anal. Biochem. 1981, 116(1), 103-110.
[15] M.R. Lee, I. Shin, Org. Lett. 2005, 7, 4269-4272.

[16] A. Lohse, R. Martins, M. R. Jørgensen, O. Hindsgaul, Angew. Chem. Int. Ed. 2006, 45, 4167-4172.

[17] K. Yamamoto, T. Tsuji, T. Osawa, Carbohydr. Res. 1982, 110, 283-289.

[18] a) V. V. Rostovtsev, L. G. Green, V. V. Fokin and K. B. Sharpless, Angew. Chem. Int. Ed. 2002, 41, 2596-2599; b) C. W. Tornoe, C. Christensen and M. Meldal, J. Org. Chem., 2002, 67, 3057-3064; c) C. S. McKay, M.G. Finn, Chem. Biol. 2014, 21(9), 1075-1101.

[19] a) D. C. Rideout, R. Breslow R J. Am. Chem. Soc. 1980, 102, 78167817; S. Narayan, J. Muldoon, M. G. Finn, V. V. Fokin, H. C. Kolb, K. B. Sharpless K.B. Angew. Chem. Int. Ed. 2005, 44, 3275-3279.

[20] A. Berkin, B. Coxon, V. Pozsgay, Chem. Eur. J. 2002, 8(19), 4424-4433.

[21] a) M. N. Yousaf, M. Mrksich, J. Am. Chem. Soc. 1999, 121, 4286-4287; b) X-L. Sun, C. L. Stabler, C. S. Cazalis, E. L. Chaikof, Bioconjugate Chem., 2006, 17(1), 52-57; c) H. S. G. Beckmann, A. Niederwieser, M. Wiessler, V. Wittmann, Chem. Eur. J. 2012, 18, 6548 - 6554

[22] A. H. El-Sagheer, V. V. Cheong, T. Brown, Org. Biomol. Chem., 2011, 9 232-235.

[23] C. Wellner, H-A. Wagenknecht, Org. Lett. 2014, 16(6), 1692-1695.

[24] a) A. Gandini, Prog. Polym. Sci. 2013, 38, 1- 29 ; b) M. A. Tasdelen, Polym. Chem. 2011, 2, 2133-2145; c) C. García-Astrain, K. González, T. Gurrea , O. Guaresti , I. Algar, A. Eceiza , N. Gabilondo, Carbohydr. Polym. 2016, 149, 94-101; d) M. Fan, Y. Ma, Z. Zhang, J. Mao, H. Tan X. Hu, Mater. Sci. Eng. C Mater. Biol. Appl. 2015, 56, 311-317; e) A. Duval, H. Lange, M. Lawoko, C. Crestini, Green Chem. 2015, 17, 4991 5000 .

[25] S. Drouillard, H. Driguez, E. Samain, Angew. Chem. Int. Ed. 2006, 45, 1778-1780

[26] M. Randriantsoa 2008, Microbiologic synthesis of saccharidic blood group antigens, phD thesis, Université Joseph Fourier, Grenoble.

[27] H. Akizawa, M. Imajima, H. Hanaoka, T. Uehara, S. Satake, Y. Arano, Bioconjugate Chem. 2013, 24, 291-299.

[28] O. Lockhoff, Angew. Chem. Int. Ed. Engl. 1991, 30, 1611-1620.

[29] L. Blomberg, J. Wieslander, T. Norberg, J. Carbohydr. Chem. 1993, 12(3), 265-276.

[30] T. Montier, P. Delepine, T. Benvegnu, V. Ferrieres, M-L. Miramon, S. Dagorn, C. Guillaume, D. Plusquellec, C. Ferec, Blood Cells Mol. Dis. 2004, 32, 271-282.

[31] a) W. Spevak, F. Dasgupta, C. J. Hobbs, J. O. Nagy, J. Org. Chem. 1996, 61(10), 3417-3422; b) D. Ramos, P. Rollin, W. Klaffke, J. Org. Chem. 2001, 66(9), 2948-2956; c) S. Halila, M. Manguian, S. Fort, S. Cottaz, T. Hamaide, E. Fleury, H. Driguez Macromol. Chem. Phys. 2008, 209, 1282-1290.

[32] a) S. De Medeiros Modolon, I. Otsuka, S. Fort, E. Minatti, R. Borsali, S Halila Biomacromolecules 2012, 13, 1129-1135; b) A. Petrelli, R. Borsali, S. Fort and S. Halila Chem. Commun. 2016, 52, 12202-12205.

[33] a) I. Otsuka, S. Tallegas, Y. Sakai, C. Rochas, S. Halila, S. Fort, A Bsiesy, T. Baron, R. Borsali Nanoscale 2013, 5, 2637-2641; b) J. D. Cushen, I. Otsuka, C. M. Bates, S. Halila, S. Fort, C. Rochas, J. A. Easley, E. L. Rausch, A. Thio, R. Borsali, C. G. Willson, C. J. Ellison ACS Nano 2012, 6, 3424-3433, c) K. Aissou, I. Otsuka, C. Rochas, S. Fort, S. Halila R. Borsali Langmuir 2011, 27(7), 4098-4103.

[34] B. Svensson, K. Larsen, A. Gunnarsson, Eur. J. Biochem. 1986, 154 497-502.

[35] S. F. H. James B. Sumner, J. Bacteriol. 1936, 32, 227-237.

[36] E. J. Yunis, J. M. Svardal, R. A. Bridges, Blood 1969, 33 (1), 124-132.

[37] The $\mathrm{N}$-acetate group displays a restricted rotation around the $\mathrm{C}-\mathrm{N}$ bond, giving rise to multiplicity of signals in the carbon and proton NMR spectra This phenomenon is well documented in the literature (see for example Reference 31a) and could not be completely avoided even by a temperature increase during the spectra acquisition. 